Volume 10 Issue 4

October 2019

\title{
Towards an Indigenous-Informed Relational Approach to Free, Prior, and Informed Consent (FPIC)
}

Terry Mitchell

Wilfrid Laurier University, tmitchell@wlu.ca

Courtney Arseneau

Wilfrid Laurier University, carseneau@wlu.ca

Darren Thomas

Wilfrid LaurierUniversity, dthomas@wlu.ca

Peggy Smith

Lakehead University, pasmith@lakeheadu.ca 


\title{
Towards an Indigenous-Informed Relational Approach to Free, Prior, and Informed Consent (FPIC)
}

\begin{abstract}
International and domestic rights frameworks are setting the stage for the full recognition of Indigenous Peoples' rights in Canada. However, current political promises to restore Indigenous relations, to reconcile historic wrongs, and to foster mutual prosperity and well-being for all people within Canada remain woefully unfulfilled. Indigenous Peoples continue to call for full engagement with emerging Indigenous rights frameworks such as the United Nations Declaration on the Rights of Indigenous Peoples (UNDRIP) and its principles of free, prior, and informed consent (FPIC). This article discusses the key findings from a multi-year university-community research partnership with Matawa First Nations in which we collaboratively seek to advance understanding of consultation processes and Indigenous experiences of and perspectives on FPIC. The article, based on several years of dialogue and interviews and a two-day workshop on FPIC, offers insight into Indigenous perspectives on FPIC advancing an Indigenous-informed relational approach to consultation and consent seeking.
\end{abstract}

\section{Keywords}

Indigenous Peoples, United Nations Declaration on the Rights of Indigenous Peoples, UNDRIP, FPIC, consent, consultation, relational approach

\section{Acknowledgments}

We wish to acknowledge the leadership role played in the development of this article by the Matawa chiefs with the support of the Regional Priorities and Jurisdiction Team. Although all nine Matawa chiefs and the numerous Matawa staff are not listed as co-authors, they guided the results in this article through their facilitation of meetings with Matawa community members and by reviewing and making constructive suggestions for improvements to the article. We thank them for their guidance, support, and contributions to understanding and knowledge. The authors have sole responsibility for the final content. We also thank the Social Sciences and Humanities Research Council, Canada for generous funding from grant (Grn-435-2015-1302: Mitchell) and Laurier University's Research Ethics Board for their review of this research project.

\section{Creative Commons License (c) $(1) \Theta(9)$}

This work is licensed under a Creative Commons Attribution-Noncommercial-No Derivative Works 4.0 License. 


\section{Towards an Indigenous-Informed Relational Approach to Free, Prior, and Informed Consent (FPIC)}

I think the issue is really: How do we strengthen ourselves so that we will be able to assert a course of our own self-determined development as well as our right to control, manage, and own our own lands and territories? (Victoria Tauli-Corpuz, United Nations Special Rapporteur on the Rights of Indigenous Peoples; Tauli-Corpuz, 2018)

Internationally, the rights of Indigenous Peoples are increasingly being recognized since the signing of the United Nations Declaration on the Rights of Indigenous Peoples (UNDRIP; UN, 2007). In the past decade, pressure has intensified on the Canadian government to fulfill the Crown's duty to honour Indigenous Peoples' Aboriginal and treaty rights. In addition to the Declaration, the Government of Canada is tasked with addressing the 94 calls to action in the Final Report of the Truth and Reconciliation Commission of Canada (TRC, 2015). These include the call to "commit to meaningful consultation, building respectful relationships, and obtaining the free, prior, and informed consent of Indigenous Peoples before proceeding with economic development projects" (Call No. 92i; TRC, 2015, p. 1).

International and domestic rights frameworks are setting the stage for the full recognition of Indigenous Peoples' rights in Canada. However, current political promises to restore Indigenous relations, to reconcile historic wrongs, and to foster mutual prosperity and well-being for all people within Canada remain woefully unfulfilled. Indigenous Peoples and allies continue to call for full engagement with emerging Indigenous rights frameworks such as UNDRIP and its principles of free, prior, and informed consent (FPIC) as outlined in Articles 10, 11.2, 19, 28, 29.2, and 32.2.

This article will examine the FPIC principles from the perspectives of Indigenous Peoples from northern Ontario who participated in a workshop about consultation and consent. We will advance conceptualizations of the principles of free, prior, and informed, and the concept of consent, arguing that the lessons learned from community voices contribute to understandings of FPIC beyond that which is currently represented in technical and legal documents. We will expand our analysis of these findings by comparing them to existing definitions of FPIC and will propose an Indigenous-informed relational approach to understanding processes of free, prior, and informed consent seeking.

\section{Literature Review}

This literature review will explore FPIC within the international human rights system; definitions of free, prior, and informed consent; Canada's shifting position on FPIC; and Indigenous perspectives on FPIC.

\section{FPIC within the International Human Rights System}

Indigenous rights to land and resources are inherent rights within an Indigenous ontology. These inherent rights are, however, increasingly elaborated in international Indigenous rights frameworks. UNDRIP (UN, 2007), for example, requires FPIC for "relocation” (Article 10); "disposal of hazardous materials" (Article 29.2); "military activities" (Article 30), and "before adopting and implementing legislative or administrative measures" that may affect Indigenous Peoples (Article 19). FPIC is also required in relation to the much broader issue of "land and resources" with the necessity of governments 
and industry obtaining FPIC "prior to the approval of any project affecting their [Indigenous] lands or territories and other resources, particularly in connection with the development, utilization or exploitation of mineral, water or other resource" (Article 32.2). UNDRIP also calls for redress for "cultural, intellectual, religious and spiritual property taken without FPIC" (Article 11.2), as well as "redress for lands, territories or resources which have been confiscated, taken occupied, used or damaged without FPIC” (Article 28).

While declarations such as UNDRIP are not legally binding instruments, conventions such as the International Labour Organization's (ILO, 1989) Indigenous and Tribal Peoples Convention No. 169 (ILO\# 169) are. Consent in ILO 169 is required only in Article 16 on relocation. Article 6, on the other hand, speaks of the objective of "achieving" rather than requiring consent, a critical issue of distinction that has led some legal scholars to conclude that UNDRIP advances a higher standard by requiring governments and proponents not only to seek but also to secure consent as illustrated in the text of Articles 19 and 32 of UNDRIP (Boutilier, 2017). Article 19 of UNDRIP (UN, 2007), for example, requires states to consult in good faith with Indigenous Peoples "through their own representative institutions in order to obtain their free, prior and informed consent before adoption and implementing legislative or administrative measures that may affect them." Article 32 of UNDRIP also obliges states to meet with potentially affected communities to obtain their "free prior and informed consent prior to the approval of any project affecting their lands or territories and other resources.”

Ten years prior to the signing of UNDRIP, the Committee on the Elimination of Racial Discrimination (CERD, 1997) of the Office of the High Commissioner for Human Rights (OHCHR) included reference to the rights to free and informed consent and reparation. Indigenous rights to free and informed consent were identified in terms of both lands and resources. Prior was mentioned in regard to the need for reparation when consent was not sought and obtained in advance of incursion onto Indigenous territories. OHCHR (1997) directed states to:

Recognize and protect the rights of indigenous peoples to own, develop, control and use their communal lands, territories and resources and, where they have been deprived of their lands and territories traditionally owned or otherwise inhabited or used without their free and informed consent, to take steps to return those lands and territories. (No. 23, Part 5)

Two years before the UN General Assembly adopted UNDRIP, a comprehensive legal commentary on the concept of FPIC was prepared for the UN Sub-Commission on the Promotion and Protection of Human Rights Working Group on Indigenous Populations. It summarized the essential and immutable qualities of the principles of FPIC that are still illusive in practice today. The report provides a clear understanding of Indigenous Peoples' inherent rights and the right to self-determination, with attention to the significance of treaty-based relationships in supporting meaningful self-determined development, which necessitates the full expression of the right to FPIC. In this early definition of FPIC, the authors had already indicated the Indigenous perspective on the importance of equal and respectful relationships:

The right to free, prior and informed consent is grounded in and is a function of indigenous peoples' inherent rights to freely determine their political status, freely pursue their economic, social and cultural development and freely dispose of their natural wealth and resources-a 
complex of inextricably related and interdependent rights encapsulated in the right of selfdetermination, to their lands, territories and resources, where applicable, from their treaty-based relationships, and their legitimate authority to require that third parties enter into an equal and respectful relationships $[$ sic $]$ with them based on the principle of informed consent. Procedurally, free, prior and informed consent requires processes that allow and support meaningful and authoritative choices by indigenous peoples about their development paths. (Motoc \& Tebtebba Foundation, 2005, p. 15)

All of these rights frameworks, some of which constitute international law, articulate consent seeking as a non-coercive process that ensures both adequate time and transparent information in an accessible format to the rights holders. Significantly, consent to access and develop Indigenous lands and resources is premised on the fundamental Indigenous right of self-determination, a foundational principle confirmed in UNDRIP and in Articles 1 and 3 of the Charter of the United Nations. The Declaration on the Granting of Independence to Colonial Countries and States (UN General Assembly, 1960) stated: "All peoples have the right to self-determination. By virtue of that right they freely determine their political status and freely pursue their economic, social and cultural development" (Article 2). The right of self-determination necessarily then presumes FPIC and the right of Indigenous Peoples to grant or provide consent to development on their lands and territories and those that will affect their resources (Ward, 2011).

\section{Defining Free, Prior, and Informed Consent}

Reviewing the literature on FPIC reveals that there is no one commonly accepted definition of FPIC. In particular, there is little to no consensus on what the individual terms free, prior, informed, or the word consent mean, nor how these rights would be implemented or monitored. Non-governmental organizations such as Oxfam (2015) have, however, defined FPIC in relation to proposed development as the "principle that indigenous peoples and local communities must be adequately informed about projects that affect their lands in a timely manner, free of coercion and manipulation, and should be given the opportunity to approve or reject a project prior to the commencement of all activities" (p. 6). The right to give or withhold consent was further elaborated by Weitzner (2011) as the "right to agree to or to reject activities or plans affecting their ancestral territories, and in cases of agreement, to determine the conditions and terms for proceeding" (p. 2). In looking across the literature, there are in fact very few attempts to provide definitions, excluding Oxfam, the Boreal Leadership Council (BLC, 2012), the Office of the High Commissioner of Human Rights (OHCHR, 2013), and the Food and Agricultural Organization (FAO, 2016) of the United Nations, which have provided definitions for some of the terms. Documents by the few organizations that have begun to define the independent terms within FPIC were, therefore, used to determine how these non-Indigenous UN agencies and nongovernmental organizations are attempting to operationalize the concept of FPIC and the individual components of free, prior, informed, and consent.

Free. The Office of the High Commissioner of Human Rights (OHCHR, 2013) and the Boreal Leadership Council (BLC, 2012) have articulated free to mean no coercion, bribery, rewards, intimidation, or manipulation. The FAO (2016) elaborated that free means not being rushed by external timelines and that decisions are made voluntarily, with the rights holders determining the process, timelines, and decision-making structure. 
Prior. The BLC (2012) stated that consent should be sought before governments grant land tenure and associated permits for exploration with time for early identification of environmentally or culturally sensitive areas. The importance of respecting time requirements for Indigenous consultation and consensus processes and the necessity of seeking consent before any authorization of any activities was emphasized in the definition of prior by OHCHR (2013). The FAO (2016) further articulated the need to consult prior to each phase of the project and that "the decision-making timeline established by the rights holders must be respected, as it reflects the time needed to understand, analyze and evaluate activities under consideration in accordance with their own customs" (p. 15).

Informed. Informed was defined by $\mathrm{OHCHR}$ (2013) as a process that requires understanding the nature, size, pace, reversibility, scope, purpose, duration, and locality of the proposed project, as well as a preliminary assessment of the likely economic, social, cultural, and environmental impacts and risks. The BLC (2012) report discussed the importance of access to information that is understandable and adequate in order to make informed decisions "based on balanced information from multiple sources" (p. 8). They emphasized "the development of an open, mutually respectful relationship between developers and Aboriginal communities" (p.9) that recognizes traditional and cultural knowledge in identifying impacts and benefits. Significantly, they indicate that information should be provided not only about the proposed project but also about the proponent, including "the company's policies, performance and reputation” (p.9). The FAO (2016) emphasized the importance of providing information "in the local language" in culturally appropriate formats which may include radio, traditional and new media, video, graphics, photos, and oral presentations (p. 15).

Consent. The FAO discussed the importance of access to information in the context of consent; that is, being fully informed "may include the option of withholding consent" (p. 2). Although consent was, interestingly, not defined by OHCHR (2013), the BLC (2012) defined consent as "the option of supporting or rejecting development that has significant impacts on Aboriginal lands or culture” (p. 4). The FAO (2016) provided a more elaborate definition of consent within FPIC as a collective right to make decisions in a cultural manner appropriate to each community:

Consent refers to the collective decision made by the rights holders and reached through the customary decision-making processes of the affected Indigenous People or communities. Consent must be sought and granted or withheld according to the unique formal or informal political-administrative dynamic of each community. (p. 16)

The FAO (2016) further defined consent as a freely given decision that may be a "yes," a "no," or a "yes with conditions" (p. 16). Significantly, the FAO articulates that consent is a collective decision (e.g., through consensus or majority) determined by the affected peoples in accordance with their own customs and traditions.

A review of the definitions and descriptions of the various component terms free, prior, informed, and consent by these three organizations reveals some consistency of meaning for FPIC. FPIC is characterized as a set of rights that enable decision making, which is realized free from coercion, within a community's own cultural framework, and with adequate time to review and assess all information necessary to make an informed judgement on the long-term risks and benefits of proposals. The information and processes supporting collective community decision making as described would enable 
communities to provide or withhold consent, to say "yes" or "no" or "yes with conditions," and to pursue further discussion and action regarding proposed developments.

In looking at the industry standard for implementing FPIC set out in 2013 by the International Council on Mining and Metals (ICMM, 2013), we can see congruency in the industry definition of FPIC with that of the FAO, BLC, and OHCHR in their articulation of a consent seeking process that is (i) free, (ii) prior, and (iii) fully informed:

Through this process indigenous peoples are: (i) able to freely make decisions without coercion, intimidation or manipulation; (ii) given sufficient time to be involved in project decisionmaking before key decisions are made and impacts occur; and (iii) fully informed about the project and its potential impacts and benefits. (p. 3)

Furthermore, the ICMM's (2013) definition of consent clearly states that Indigenous Peoples can give or withhold consent to a project:

The outcome is that indigenous peoples can give or withhold their consent to a project through a process that strives to be consistent with their traditional decision-making processes while respecting internationally recognised human rights and is based on good faith negotiation. (ICMM, 2013, p. 3)

The ICMM's (2013) report on Indigenous Peoples and mining requires all ICMM-affiliated companies to respect and implement FPIC. The report articulates that all member companies are to meaningfully engage communities and seek their definition of what would constitute consent. Furthermore, the engagement plan should define what would constitute consent from Indigenous communities.

This progressive stance on seeking Indigenous perspectives and understandings is an important element that has been lacking in the Canadian State's shifting relationship with FPIC consistent with a conspicuous absence in the general operationalization of consent seeking by both industry and governments. CERD, in responding to Canada's periodic reviews of its implementation of UNDRIP, recommended Canada "incorporate the free, prior and informed consent principle in the Canadian regulatory system” (OHCHR, 2017, para. 20d).

\section{Canada's Shifting Position on FPIC}

Despite Canada's central role in advancing human rights generally through the formation of the United Nations, Canada is not a signatory to ILO Convention 169 and refused to endorse UNDRIP at its adoption in 2007, raising objections to articles that address the principles of FPIC on the basis that they were incompatible with Canadian law (Land, 2016). The Canadian government eventually issued a "Statement of Support" to UNDRIP in 2010, with qualifications, referring to the Declaration as an "aspirational document" (Indigenous and Northern Affairs Canada, 2010, para. 3). Significant to this discussion on FPIC, in 2014, Canada was the only UN member to refuse to adopt the outcome document of the Indigenous World Conference citing objections to Article 20 that called upon states to implement FPIC (United Nations General Assembly, 2014). 
Despite Canada's resistance to the use of FPIC, both domestically and internationally, the government's Final Report of the Truth and Reconciliation Commission (TRC, 2015) calls for the full implementation of UNDRIP in Calls to Action 43 and 44.

43. We call upon federal, provincial, territorial, and municipal governments to fully adopt and implement the United Nations Declaration on the Rights of Indigenous Peoples as the framework for reconciliation.

44. We call upon the Government of Canada to develop a national action plan, strategies, and other concrete measures to achieve the goals of the United Nations Declaration on the Rights of Indigenous Peoples.

In response to both domestic and international pressures, and under a newly elected Liberal government in 2015, Canada announced the removal of its permanent objector status to UNDRIP to a standing ovation at the United Nations Permanent Forum on Indigenous Issues in May 2016. However, characteristic of Canada's contradictory relationship to UNDRIP, in July of the same year, Minister of Justice Jody Wilson-Raybould stated, "simplistic approaches such as adopting the United Nations declaration as being Canadian law are unworkable" (Justice Minister Jody Wilson-Raybould Says," 2016, para. 3). In another contradictory turn, the Government of Canada advanced the concept of FPIC in Principle 6 of their newly formulated Principles Respecting the Government of Canada's Relationship with Indigenous Peoples (Department of Justice, 2018). However, the language is weak and refers to "aiming" to secure rather than requiring consent:

The Government of Canada recognizes that meaningful engagement with Indigenous peoples aims to secure their free, prior, and informed consent when Canada proposes to take actions which impact them and their rights, including their lands, territories and resources. (p. 12)

Understanding the implementation of FPIC in Canada involves complex legal, ethical, and economic considerations, as well as an awareness of the ways FPIC is applied across different jurisdictions. Jurisdiction is particularly important when it comes to natural resource development and management because, although the federal government has constitutional responsibility for "Indians and Lands reserved for the Indians" (Constitution Act, 1867, s. 91(24)), the provinces have constitutional authority over natural resources within their boundaries (Constitution Act, 1867, s. 92A). The definition of FPIC and consent within FPIC, therefore, becomes even more important, particularly from an Indigenous perspective.

Following the affirmation of Canada's duty to consult Indigenous Peoples to avoid infringement of their Aboriginal and treaty rights (Constitution Act, 1982, s. 35), a number of Supreme Court of Canada (SCC) cases have helped to clarify what the elements of meaningful consultation are, some of which mirror FPIC principles. The Court has reiterated the Crown's (both federal and provincial governments) duty to consult and accommodate in any matter that may impact potential or established Aboriginal or treaty rights (Haida First Nation v. British Columbia, 2004; Mikisew Cree First Nation v. Canada, 2005) and, in some cases, compensate for infringements on their rights (Delgamuukw v. British Columbia, 1997). The Clyde River decision (Clyde River (Hamlet) v. Petroleum Geo-Services Inc., 2017) articulates the ways in which the territory and the proponent did not meet the standards of consultation. The SCC found that the National Energy Board (NEB) did not address the treaty rights of 
the Clyde River people to hunt marine animals nor development's potential impact on their rights, the Crown did not adequately explain how the NEB would fulfill its duty to consult, and the Crown failed in its duty to conduct "deep consultation" (Introduction section, para. 7). The SCC explained that deep consultation "may entail the opportunity to make submissions for consideration, formal participation in the decision-making process, and provision of written reasons to show that Aboriginal concerns were considered and to reveal the impact they had on the decision (Haida, at para. 44)" (Clyde River (Hamlet) v. Petroleum Geo-Services Inc., 2017, para. 47). Further, a lengthy and complex ruling of the Federal Court of Appeal ( Tsleil-Waututh Nation v. Canada (Attorney General), 2018) concluded that the federal government failed in its duty to engage in meaningful consultation with First Nations and that the NEB's report was so flawed that it could not be used as a basis for government decision making regarding approval of the expansion of the Trans Mountain pipeline.

Central to our argument on the importance of a relational approach to engaging in appropriate consultation processes that recognize and respect FPIC, the Federal Court of Appeals determined that the Crown's consultation process was "missing a genuine and sustained effort to pursue meaningful twoway dialogue" ( Tsilhqot'in First Nation v. British Columbia, 2014, para. 756). Additional case law has affirmed that consent must be obtained from Aboriginal titleholders (a unique form of ownership of land) and that title may be proven by demonstrating ongoing, exclusive occupation and use of territory.

Significantly, within Matawa First Nations, a recent Ontario Superior Court (ONSC) ruling Eabametoong First Nation v. Minister of Northern Development (2018) revealed that the Ontario Ministry of Northern Development and Mines failed to properly consult with Eabametoong First Nation before granting a gold mining permit to industry. The ruling issued by three judges stated: "The ministry's conduct cannot reasonably be considered to be the type of conduct that would promote reconciliation between the Crown and Indigenous Peoples" (para. 121). The decision further clarified that proper consultation would require "managing the consultation process in a way that fosters trust as opposed to misunderstanding and betrayal” (para. 121).

\section{Advancing Indigenous Perspectives on FPIC}

The repeated failure of government and industry to adequately consult Indigenous communities has raised debate about the legitimacy of UNDRIP and the usefulness of FPIC in practice (Craft et al., 2018; Hewitt, 2018; Morales, 2017). Concerns have also been raised that “... the concept of FPIC will be undermined and divorced from the right to self-determination if actors other than Indigenous Peoples themselves attempt to define it and control its operationalization” (Doyle \& Cariño, 2013, p. 3). Canadian Indigenous legal scholar, John Borrows (2018), however, asserts the importance of FPIC as outlined in UNDRIP:

UNDRIP changes Canada's relationship with Indigenous peoples in terms of the duty to consult by saying that the honour of the Crown, which is part of the legal duty to consult, must involve the free, prior and informed consent of Indigenous peoples. What that means is that when the Crown is exercising its powers to develop, that is has to ensure that honour involves the free will, or the participatory actions of Indigenous peoples in that goal. (para. 5)

Many Indigenous leaders have embraced FPIC as a means of protecting their territories from proposed extractive projects even as they critique current government practices of consultation and consent 
seeking. Arthur Manuel (2017), in his book The Reconciliation Manifesto: Recovering the Land Rebuilding the Economy, wrote of the significant contributions of UNDRIP with particular reference to FPIC. In advancing six steps to decolonization, Manuel (2017) included the importance of honouring FPIC in all matters related to Indigenous lands and territories:

Anything we agree to in access and benefits must also include clear jurisdictional lines of authority based on the standard of free, prior, and informed consent of Indigenous peoples and decision making that incorporates environmental reviews and oversight in accordance with Indigenous laws. (p. 277)

However, as a member of the Secwepemc First Nation, Manuel decried the Canadian state's violation of FPIC in ongoing developments surrounding the Trans Mountain pipeline on his traditional territory.

In response to the Government of British Columbia's commitment to fully implement UNDRIP, made by the newly elected New Democratic Party (NDP) in 2017, the Union of BC Indian Chiefs (UBCIC) with the Canadian Centre for Policy Alternatives (CPPA) published a road map with recommendations on how to achieve "true, lasting reconciliation" (UBCIC \& CCPA, 2018). Again, self-determination is a driving principle and FPIC the mechanism for achieving it:

Implementation requires a focus on Indigenous self-determination. This means that implementation will look different in different places. Efforts of governments or other actors cannot prescribe, define or determine Indigenous peoples' own priorities. Crown governments must create the space that ensures they can be appropriately responsive to paths determined by Indigenous peoples. (p. 8)

Focused on meaningful consultation in environmental assessment, Udofia, Noble, and Poelzer (2017) explored northern Saskatchewan First Nations' frustration regarding the effectiveness of consultation. While not focussed on consent, the authors reflected First Nations' experience with early or "prior" engagement, noting that a lack of full information hampers "informed" consultation.

The Canadian Indigenous Bar Association advances the meaning of FPIC by referencing definitions of FPIC provided by the International Indian Treaty Council (IITC, 2013).

Free necessarily includes the absence of coercion and outside pressure, including monetary inducements (unless they are mutually agreed on as part of a settlement process), and "divide and conquer" tactics. Indigenous peoples must be able to say "no," and not be threatened with or suffer retaliation if they do so. (p. 1)

Prior means that there must be sufficient lead time to allow information-gathering and sharing processes to take place, including translations into traditional languages and verbal dissemination as needed, according to the decision-making processes of the Indigenous peoples in question. This process must take place without time pressure or time constraints. A plan or project must not begin before this process is fully completed and an agreement with the Indigenous peoples concerned is reached. (p. 1) 
Mitchell et al.: Towards an Indigenous-Informed Relational Approach

Informed means that all relevant information reflecting all views and positions must be available for consideration by the Indigenous peoples concerned. This includes the input of traditional elders, spiritual leaders, traditional subsistence practitioners, and traditional knowledge holders. The decision-making process must allow adequate time and resources for Indigenous peoples to find and consider impartial, balanced information as to the potential risks and benefits of the proposal under consideration. (p. 1)

Consent involves the clear and compelling demonstration by the Indigenous peoples concerned of their agreement to the proposal under consideration. The mechanism used to reach agreement must itself be agreed to by the Indigenous peoples concerned, and must be consistent with their decision- making structures and criteria (for example, traditional consensus procedures). Agreements must be reached with the full and effective participation of the leaders, representatives, or decision-making institutions authorized by the Indigenous peoples themselves. (p. 1)

There is a need to advance Indigenous perspectives on implementing FPIC in order to ensure that any attempt to operationalize FPIC functionally protects the rights of Indigenous Peoples and the environment in accordance with Indigenous laws. This is where our article begins. We will discuss Indigenous perspectives provided through visits and workshops with Matawa First Nations in order to extend the currently limited definitions and operationalization of FPIC by non-Indigenous governments, industry, and UN bodies and non-governmental organizations.

\section{Current Study}

This study explores Indigenous rights and resource governance within Matawa First Nations with attention to proposed mining developments in the Ring of Fire (RoF) in northern Ontario. The entire Matawa region is a mineral-rich environment with numerous active claims. Significant deposits have been identified in the region, including copper, zinc, nickel, platinum, vanadium, and gold (Ontario Chamber of Commerce [OCC], 2014). Notably, the RoF includes a large chromite deposit with a value estimated at over $\$ 60$ billion (Chong, 2014). The RoF is located approximately 540 kilometers northeast of Thunder Bay, Ontario (OCC, 2014). This area is within the Treaty 9 (1905-1906, adhesions 1929-1930) boundaries and is the ancestral home of Anishinaabe (Ojibway), Mushkegowuk (Cree), and Oji-Cree Nations. Matawa First Nations Management is a tribal council formed in 1988 to support nine First Nation member communities in the region: Aroland, Constance Lake, Eabametoong, Ginoogaming, Long Lake \#58, Nibinamik, Marten Falls, Neskantaga, and Webequie. With a total membership population of 9,500, Matawa First Nations have unique sets of needs and priorities - with some communities accessible by road (Aroland, Constance Lake, Ginoogaming, and Long Lake \#58) and others accessible by air or winter roads (Eabametoong, Nibinamik, Marten Falls, Neskantaga, and Webequie).

Several Matawa First Nations are familiar with forestry and some may have benefitted from employment opportunities in the forest sector. With the amendment of the Mining Act (1990) beginning in 2009 and 
the implementation of the Far North Act in 2010, ${ }^{1}$ the Province of Ontario developed protocols for actively engaging Indigenous communities to consider resource extraction as an economic strategy to enhance their infrastructure development. Matawa First Nations are engaged in a process of discussing scientific reports, full of complex technical language, in their efforts to develop a common understanding and collective decision-making process on whether or not to proceed with the proposed development in their territories.

\section{Research Partnership}

This study is the result of an ongoing research partnership with Matawa First Nations to better understand Indigenous Peoples' experiences of consultation and consent during their negotiations around resource development. The research partnership aims to advance understanding of FPIC principles from a local Indigenous perspective while also promoting FPIC as a valuable tool for asserting Indigenous Peoples' rights globally. This research, funded by the Social Sciences and Humanities Research Council of Canada (SSHRC), was approved by our university Research Ethics Board in alignment with a research protocol that was established with Matawa First Nations Tribal Council support staff and endorsed by the Matawa Chiefs Council.

The findings reflect our learning from 3 years of meeting and visiting with the chiefs, support staff, and community members of Matawa First Nations, with specific concepts derived from a two-day meeting about FPIC co-organized by Matawa First Nations Management and our research team. The meeting, which involved a public talk and a private consultation with the United Nations Special Rapporteur on the Rights of Indigenous Peoples, Victoria Tauli-Corpuz, provided an opportunity for participants to share their experiences of consultation and FPIC processes in resource development across three regions: northern Ontario (Matawa), the Northwest Territories, and Chile. Although attendees from all regions participated in all events, for the purpose of the current study, the data reported here draws largely from Matawa participants.

\section{Methods}

\section{Participants}

Over 30 people participated in the FPIC workshop. Of these participants, 17 represented Matawa First Nations, 7 were invited guests from other Indigenous communities, and the rest were members of the research team. Participants were invited to the workshop based on their traditional and professional roles in resource governance matters in their own communities. Recruitment was facilitated by management and staff at the tribal council and the workshop was hosted at the Matawa regional office in Thunder Bay, Ontario.

\footnotetext{
${ }^{1}$ In February 2019, the Progressive Conservative government under Premier Doug Ford, elected in June 2018, announced a review of the Far North Act and proposed to repeal the Act to reduce red tape and promote economic development in the region (McKenzie, 2019). 


\section{Materials}

Audio recorders were used with permission throughout the meetings. For the structured workshop on the second day, conversation guides were prepared for each facilitator. Open-ended questions guided participants in considering what each FPIC principle meant to them in the context of their communities. For example, participants were asked, "What does it mean for consent to be free?" "What kinds of things make a decision not free?" "What has your experience been so far around free consent?" Similar questions were asked about the principles of prior and informed. A simple presentation slide was projected in the room with basic definitions of each FPIC principle to provide a starting point for the conversation. The definitions were drawn from a report written by the Sustainable Development Institute (2015) that was selected for its community-friendly, accessible language. For example, in advance of a dialogue about free consent, we proposed this definition: "Free means no coercion, intimidation, inducement, or manipulation" (p. 6).

\section{Procedure}

Following a traditional welcome, the research team introduced themselves and discussed the purpose of the FPIC meeting. The team then explained the details of the consent forms, which participants signed. While every effort was made to remove any potential identifiers of individual participants, the researchers discussed that anonymity could not be fully guaranteed because of the nature of the case study. The team also obtained permission to audio record the two-day event and to use quotations in our research reports and deliverables.

The first meeting day created space for open dialogue (in both large and small groups) about community experiences with resource development. The second day concluded with a structured workshop on FPIC. Following the two-day meeting, all audio recordings were transcribed. All transcripts were reviewed independently by three coders who thematically analyzed the data for conceptualizations of "free," "prior," "informed," and "consent." The coders met frequently to debrief and dialogue about emerging key themes and ideas, which are presented below. In compiling a synthesis of the results, the research team prepared a report for Matawa First Nations management and Chiefs Council.

\section{Findings}

Below is a summary of workshop participants' perspectives on the meaning of FPIC. In a facilitated workshop, we sought community-based definitions of FPIC by asking participants to describe from their experiences what free, prior, and informed consent seeking processes would look like from their perspectives and how they would define or describe each of the individual components of FPIC. The following descriptions from the workshop provide insight into Indigenous perspectives in our efforts to expand upon current conceptualizations of FPIC found in technical documents and to address the significant lack of Indigenous voice in the literature.

\section{Free Consent}

Participants discussed free consent in terms of meaningful, equal partnerships between First Nations and the provincial or territorial governments that respect and honour their inherent and treaty rights. 
Free consent was believed to be a process for consultation and decision making determined by First Nations free from coercion, on their own terms, with respect for time and community capacity and recognition of inherent rights.

Free from coercion. Some participants stated that current consultation processes do not respect the right to free consent, often involving forms of intimidation, inducement, manipulation, and misrepresentation of consultation and consent.

No we didn't give, we didn't give any, we didn't give [Indigenous language] we didn't give approval, you know? They just came in and talked about the project and someone translated.

From a First Nation's perspective, it's not free. It's imposed on us; you're manipulated. Force, intimidation, inducement, manipulation - it's all there. How [do] you deal with it ... I think you pretty much have to stand up, but you stand up collectively and have to do it in unison.

You know that question about getting consent, there's a check mark. So we went around asking people in the territory, they said "No, we don't even know what they look like." So sometimes they'll sneak in a check mark, so you know it's a go ahead. Like I said, free, prior, and informed, we're informed, but they don't want to use traditional knowledge. They don't want to hear.

Free from financial ties. Other participants noted that while coercion may not always be intentional, they were concerned with indirect forms of intimidation such as communities feeling pressured to make a decision associated with government-funded consultation processes.

At what price are we doing that free, prior and informed consent? And I'm talking about the Ring of Fire. We are being consulted, we are given this information. But at what cost? ... For me I'm scared 'cause ... they're paying for our free, prior, and informed consent process. At what cost are we doing it? At the end of the day, they say, "Well we've told you what we want. We informed you. We came to see you. We were in your community, we made presentations. OK what are you gonna do for us?" And when that comes, we're gonna be obligated to say, "Let's go.” And our land is gonna be destroyed 'cause it wasn't our money. That's what I'm afraid of.

There is no free, until the day we make our own money, have our own set of language ... we're always trying to adapt to something. And we're always trying to fit our triangle into that circle. It should be the other way around. It is our triangle, ok you guys fit into it [...] So free is lost. It's the language. It's where your money is coming from. It's who's pulling the strings.

Participants spoke about how First Nations cannot give consent freely without being equal in their relationship with the provincial government. For example, participants said that First Nations are expected to respond and provide their input on proposed plans without having adequate resources, staff, and time to do so. Communities quickly become inundated with an overwhelming amount of work to do and participants discussed feeling as though First Nations are always having to catch up to the timelines and agendas imposed by the provincial government.

You know there's pressure even in our own local government to produce. Right now I got an email from the Ring of Fire. They're setting up another table. But yet our people haven't even 
gotten that far yet. So how can the chiefs present to the government, to the negotiators what our people are saying? So, the free will never be there until we are equal partners 'cause we're always behind. We're always behind.

Adding to this pressure, participants pointed to the need for communities to quickly learn specialized technical knowledge about development and the mining cycle. To have an equal partnership between First Nations and the provincial government, participants stressed that the imbalance in resources and capacity must be addressed - this is required before consent can be freely sought.

The government has beefed up their staff to comply, to make sure that this follows through. On the other hand, First Nations are understaffed because they don't control the money. So, they [government] beef up their staff, but on the other hand they expect First Nations to comply with inadequacy of funds or skills or the time.

Respect for Indigenous rights. Participants pointed out that free consent would require honouring the inherent and treaty rights of Indigenous Peoples in making decisions about their traditional lands and territories. Indigenous Peoples' right to protect the land and its resources is an inherent responsibility that cannot be taken away or given up.

We have inherent responsibilities about what the community does. We have to learn that if we inherit something, we have to follow through with those principles [...]. When they signed the treaty, they didn't give up their inherent right, they didn't give up their land. There's no such thing as surrender. How can you give someone what is your inherent [right]? It's just not possible. But that's why the laws are different. Their ideology is different; our ideology is sharing.

Participants discussed how the process of providing FPIC is not free if Indigenous communities continually have to "prove" their inherent rights and to repeatedly assert their jurisdiction over their territories prior to exploration and staking of their lands.

\section{Prior Consent}

Matawa First Nations have considerable experience with prospecting and development happening prior to authentic consultation rather than consultation happening prior to incursions into their territories. Participants shared many examples of trespassing on their lands and their earlier recommendations for consultation prior to exploration.

Matawa communities, 10 years ago or so, we made some recommendations about mining and one of them was that we felt that consultation starts very early in terms of even before exploration happens. It should happen at a time when there is prospecting or even before that. And that was one of our recommendations. And that recommendation was never honoured... some mining companies don't have no idea how to do consultation at all.

Traditional community consensus processes. An Elder spoke in Oji-Cree to explain what "prior” meant to him. It meant having the information that is needed for a community to consider an issue, problem, or opportunity, to engage in discussion, and to seek a decision through a collective process of 
consensus building. He described a process of asking and agreeing with respect, saying that decisions that arise from a consensus building process are needed for community stability.

Prior means information. It means the information is given to you in advance ... so you could say yes or no. You're acting to reach that consensus, that's an activity. Consensus processes are respected [...] To ask and agree with respect. Respecting your decisions. Consensus is a unified decision. Everybody agrees. Well, everybody is asked and everybody agrees. Consensus we're trying to bring something together so that the community can have respect. If you don't do something together you have a hard time with stability. [Translated from Oji Cree]

Capacity building. Participants were very clear that greater amounts of time must be invested in meeting with community members, providing information, and building community capacity to understand the various components necessary for informed participation and decision making prior to all phases in the mining cycle, from exploration to mine decommissioning.

With the lack of the capacity in the communities, you'll never ever get prior consent. The Ministry of Mines in Ontario is loading up on their side with qualified people that go against other people ... Where's the capacity building? There's no funding left for that. You'll never, ever get free, prior, and informed consent as long as there is no capacity.

\section{Informed Consent}

We learned from participants that the capacity required for analyzing and understanding highly scientific, technical, economic, environmental, social, financial, and legal analyses is demanding and burdensome for communities. Community members confirmed, in many cases, a lack of knowledge of their rights to FPIC and the government's duty to consult and accommodate. There were many reported instances of consultation being conducted without community members and Elders knowing that their presence was being viewed as consultation or presumed approval of industry proposals.

Awareness and knowledge of rights standards. Indigenous community members and Matawa participants stated that international Indigenous rights standards and legally protected Indigenous rights within Canada are not well known to First Nations. Community leaders and technical support experts have had to spend significant time learning about these issues:

We didn't understand when companies started to contact us, call us, have meetings with us, or come to our community, that they counted this as "consultation." We began to understand that we needed more deep consultation for us to be able to understand what is taking place in our territory. Our Elders have always said that we need to be part of the development in our area. We have to be able to be part of the processes, be part of the work that is going to come in from our lands and resources, our territories. So we needed to find out more about what we want as consultation in order for us to better understand that. We are working with government in developing that relation and we are talking about what we mean, what we want as consultation for our communities and our members.

The average person in the community does not know what FPIC is. Not just an acronym but the idea-free, prior, and informed consent. When you talk to them and ask them, they don't know. 
Everything that we talked about all day here, that's specialized knowledge for EDOs [Economic Development Officers] and for technical people in the band.

The lack of translation of highly technical language. Participants pointed out that informed consent means all information must be accessible to the entire community. Scientific information must not only be translated into plain English, but also into Indigenous languages for Elders and traditional knowledge holders:

It's supposed to be a community driven process, and when you're looking at, as I explained, the perspectives of mining, when you're looking for a community input ... it seems to be unfair to the community members because if they don't know anything about the mining perspectives, or the business side, or anything; or anything about how they will be socially impacted, they don't completely understand.

And a lot of the people in the Matawa communities ... English is their second language, they speak Ojibwe as their first language, so you're trying to translate further... Yeah, there's that barrier of the language and then even the actual perspectives of mining ... and putting the onus on the input from community members.

They carried with them English presentations but the community provided a local translator. However, from my experience in terms of the understanding the terminology that the mining companies use, as well as, there's many words that you cannot really put into our dialect, so a lot of times when I hear translators, I question what they're saying. And I think, I don't think that's a very appropriate process.

Provincial jurisdiction over Indigenous lands. Jurisdiction over lands and resources is the most significant barrier identified by participants to overcome in terms of informed consent. One example participants shared was that the concept of "free entry" in the Ontario Mining Act remains a problem for Indigenous communities because First Nation communities are not notified when prospectors are coming into their lands to stake. Once prospectors make a claim and start the planning and permitting processes, the timeline demands are unrealistic for First Nation communities to respond. Participants explained that further compromising the standard of consultation and consent seeking is the fact that First Nation communities, as a whole, have limited capacity to respond to the numerous requests that are made, which can be upwards of 300 a year. Participants said the volume of requests does not allow the principle of "prior" to be met, and it does not give power to communities to be fully informed about who, where, when, and why a prospector or company might be entering into lands to which Aboriginal and treaty rights apply.

Participants also discussed the Far North Act (2010) and concluded the Act is not much better at protecting Indigenous inherent rights because the development of community-based land use planning, enabled by the Act, is controlled by the provincial government and is not a true act of self-determination as long as a community's land use plan can be vetoed by the Ontario Minister of Natural Resources and Forestry.

Right now currently I think there are four Matawa First Nations that have controversies with mining companies ... So there is some sense of uncertainty about the legislation piece of plans 
and permits that it's not working right for First Nations. And it's a third-party designated consultation piece designed by the Ministry of Northern Development and Mines. So the proponents of the mining companies have to do the consultation. And there's no assurance of how they have to prove that they did that meaningful consultation and turn around issue permits.

Somewhere around 2001 to 2007, that's the time they tried to stake out the whole territory out there; there was no prior, informed, consent, consultation, to even consult at all. So there was a lot of activity in our area, in our backyard, a lot of disturbance in our fishing and hunting activities in that area in that time. And there was no respect at all from the industry or the governments.

That's how they divide, divide and conquer. You know? No unity. When you speak about jurisdiction, jurisdiction is your mentality, European mentality. Since time immemorial, there's no jurisdiction. That's what he's saying, no jurisdiction. There needs to be this, he [referring to Elder] calls it the [Indigenous language] which is understanding. We have to have the equilibrium of our cultures. You cannot try to make me your culture or White man, it has to be this equilibrium.

Industry needs education on Indigenous values, laws, and philosophy. Participants said they want to share and assist others in understanding their traditional knowledge and relationships to land, but they stated that many non-Indigenous communities do not wish to learn from them. Or when they do, they find a way to exploit that knowledge.

When you talk to the Elders about past time, who are still here with us, they always talk about to be careful, be careful how you're negotiating, what you do with your land. 'Cause no matter what, whatever money you make, whatever result that is coming into your territory, you're Anishinaabe. The blood that's running through your vein is Anishinaabe blood and it always wants to be in alignment. And that's very important. Without land, you're nothing, no matter how much money comes into your territory. So in negotiating, you have to be very careful how, not what. And that's why, in the Ring of Fire, you know people say what's wrong with you guys, you got really good potential coming to your territory. No, that's not how Anishinaabe looks at it, it's your environment, if you don't protect your environment, then you're nothing. That's where you're from, the water, the land, the trees.

The Chief of our community always says the Elders are our most valuable, they're more valuable than any technologist, any researcher, any specialist; they should be the highest paid, higher paid than any consultant or researcher that comes in to the community because they got the TEK [traditional ecological knowledge], they've got the knowledge. Without them, he's saying, you lose all of that and a lot of them are dying...

\section{Seeking Consent Through the Principles and Processes of FPIC}

Participants spoke of the Elders' experience of intrusion on their lands, the lack of benefits and lack of revenue sharing, as well as the tremendous costs to their territories - to their lands, waters, and cultures. 
This points to the critical need to balance risks and benefits in informed decision making and the collective consideration of providing consent for proposed development.

It's interesting to speak with them [the Elders] because their attitudes are still, "They can't do that here" [...] They've seen it [development] come and go and they've seen the lack of opportunities and the lack of revenue sharing ... there's zero revenue sharing or division of resources or any benefits to the First Nations communities, so they're very sceptical a lot of the time. They think that there could be no good coming out of it and it's just interesting because they have that experience. They watched it. They watched everything change, they watched the water get damned, to change even the directions of the river. They've seen rivers that were just a creek to now it's a river, the flooding, the hydro flooding, the land erosion. They've seen the decimation of the forests, and they've seen the gold mining projects, every single project in the area, so now they're, "OK again? It's going to happen again. What's going to be done to make sure that the communities benefit?"

Collective decision making. Matawa participants' definition of consent is premised on the practice of Indigenous collective and consensual decision making before their lands are accessed, and well before any political, technical, mechanical, environmental, industrial or financial decisions are made about exploring or extracting resources from their territories. Consent building was described as being contingent upon relationship, respect, and mutual benefit derived through power sharing throughout the processes of consultation at any and all stages of development:

(We) need some clear definitions for consent and consult. And the combinations, like the word, what is it? A lot of community members and others have their different definitions. But it seems like if there's a process that $100 \%$ benefits the industry ... If there was a way to codify FPIC or something so that you could see the First Nations deriving just as much if not more benefit than mainstream Canada, than industry proponent, then why not? Why not share power? I think a lot of it is refusal, denying the sharing of power. They just don't want to share benefit and share power.

We have a large say in what happens. So even socio-economic wise, it will enhance our involvement as an equity partner in whatever development happens in our territory, that consent is giving by our people, in our community, in our nations ... So right now it appears that the Ontario government is dictating whatever is going to happen in Ontario, so that's why our chiefs are saying, our people are saying, that's not going to happen.

Many participants spoke about the risks of not being seen as equal partners and the absence of government-to-government relationships that respect Indigenous Peoples' rights to engage in community-determined consultation processes. While consensus building among community members is the first step in information seeking and decision making, there was a clear consensus across all of the data and community meetings that understanding, developing, and sustaining respectful relationships is an essential beginning to any and all consultation and consent seeking processes. 


\section{A Relational Approach to Consultation and Consent Seeking}

Matawa First Nation members spoke of an Indigenous-informed, relational understanding of free, prior, and informed consent. In reflecting on their experiences of consultation and consent-seeking processes in their traditional territories, participants not only indicated that external governments and proponents have failed to adequately engage in meaningful relationship-building, they also clarified important criteria for what a relational approach to FPIC might look like. We learned from the communities that the implementation and fulfillment of FPIC will require further understanding of an Indigenous perspective on the importance of developing and sustaining relationships between communities and between Matawa First Nations, various levels of government, industry proponents, and the earth.

The central nature of relationships. Matawa participants saw connections between all things, including the land, as being central to their worldview:

When I go to work, or when I attend a meeting, I know to at least acknowledge people regardless of their race, regardless of their creed, regardless of their belief. I have to acknowledge people because we're all one and equal. That's one thing I always live by is that we're all one and equal. I just wanted to share that message because it is really important to be reminded at times of that ... sometimes we have to be pulled back to the same level, to the ground, to the earth.

My understanding as an Anishinaabe is that we have sacred connection to the land, we are connected to everything, and that is my belief. That's something that I cherish, that is something that I carry with me every day. We are connected to the land. And like one of my colleagues said, money will run out. But our connection to the land as well as our stewardship to the land is something that we really need to look at when making our decisions in the future because we're only borrowing the land. We're only using it temporarily because we have to leave the rest to our children, for those that are going to live in the future.

\section{Working relationships require all parties to be informed and to respect treaty rights. Matawa} members stated that they wanted to build a relationship with industry and external governments as part of their decision-making process and exercise of their inherent rights of stewardship of their lands. Relationship building was discussed as a process that would start early in the mining cycle, before any development related activity and described as the "prior to the prior," requiring a large time commitment as well as attention to ensuring that all parties are informed and respect treaty rights.

We have to safeguard our Aboriginal and treaty rights, things that are within us. Our culture has to be safeguarded and protected. But it has to be protected in a way that everything will work in harmony. So that's how we view it. And that's how we want to move forward in our relationship with industry and also with government.

Sometimes for consultation and accommodation, they come to see you, shake hands with you and have a coffee. That's not a true consultation process. If you want to truly create a working relationship for development, you have to know the concepts and teachings of how the important pieces of the development will occur, and when and how. 
Some of our communities have developed consultation protocols. Whenever mining companies enter into their territory, they advise the mining company that here is our protocol, here is how we want you to consult with us. We want you to build a relationship with us ... As the Chief mentioned, we believe that relationship building is a must [...] Certainly we would like to hear from these prospectors coming into our territory. And then once exploration starts, when staking is done. I believe there isn't a lot of consultation taking place prior to that. And what happens sometimes is the property changes hands [between exploration companies], and that leaves First Nations with a broken relationship of consultation.

We believe that the actions of the government do not honour what we agreed upon in the treaty. It doesn't honour the inherent right of our peoples on the land. We're dealing with trying to recognize what they mean by consultation. And our viewpoints are different in our First Nations. We're trying to build back relationships; we're trying to understand each other. And that's going to take some time.

Significant demands upon communities to understand mainstream government and industry information, policy, and laws were detailed. Matawa members recounted how they were required to develop various capacities to understand the perspectives of provincial and territorial governments and industry proponents. On the other hand, these members pointed out that governments and industry were not building their own capacity to understand Indigenous laws, protocols, and languages, and meanings attributed to relationships, nor were these proponents building their capacity to apply the principles of free, prior, and informed consent.

\section{Discussion}

From our communication with case study participants, it is evident that despite Canada's endorsement of UNDRIP, Indigenous communities have not experienced processes of engagement aligned with their understanding of UNDRIP and the meanings they attribute to FPIC regarding proposed development on their territories. There remains a growing chasm between the interpretation and application of FPIC of Indigenous Peoples and that of both governments and industry despite some congruence in textual definitions.

In the absence of sufficient time and resources for communities to understand the complex technical information and related implications for each community's social, cultural, environmental, and economic wellness, development will continue to occur without meaningful prior consultation or the consent of Indigenous Peoples. Consultation and consent seeking processes create strains on First Nation communities demanding their time and tremendous amounts of both financial and human resources. Indigenous communities are challenged to engage with industrial technical knowledge, while following their own Indigenous laws and protecting the inherent rights of future generations.

Jurisdiction was a most significant barrier to achieving consent. The Province of Ontario asserted jurisdiction over Treaty 9 lands and developed the legislative power (e.g., Mining Act; Far North Act) to support and strengthen its jurisdiction. This was done under a cloud of criticism about the failure of the Crown to adequately consult with First Nations about these strategic decisions (Drake, 2016; Gardner, Tsuji, McCarthy, Whitelaw, \& Tsuji, 2012). Aspects of this legislation seem to actively dismiss constitutionally protected Indigenous rights. The communities have minimal influence over setting 
timelines of consultation and decision making and are subjected to the unreasonable demands to respond to Western timelines, languages, and decision-making processes, rather than government and proponents learning, respecting, and working within the framework of various cultural protocols and Indigenous law and philosophy.

Prior consent requires sufficient time to review all relevant resources in order to fully understand the potential, known, and probable impacts and benefits of the proposed development. Relationship development, the prior to the prior consent, is required to demonstrate respect for Indigenous nations' jurisdictions, cultures, and collective decision-making processes. Communities require time to arrange community information sessions and community consensus-building processes that promote agreement and unity amongst community members. Historically, the lack of prior FPIC has resulted in trespassing on Indigenous traditional territories with minimal benefit to communities. In this regard, some Matawa residents are wondering if the past will be repeated.

Growing conflicts amid the increased coercion and incursion on Indigenous territories reveals the current failure of governments and industry to recognize, understand, and respect FPIC. Indigenous Peoples, however, continue to understand and assert their rights to decision making free from coercion, prior to permitting or development, based on full information and a full understanding of the risks and benefits of proposed developments to their culture, land, water, animals, birds, fish, forest, and community. It is evident that Indigenous Peoples have a more fulsome understanding of FPIC that challenges the limited, isolated, and contradictory applications of FPIC principles by the Canadian government in which Indigenous worldviews are largely absent.

The discussions, reflections, and contributions of Matawa First Nations in advancing an Indigenous understanding of the meanings they attribute to the principles of free, prior, informed, and consent within UNDRIP fit well with those presented by the International Indian Treaty Council (IITC, 2013). The conversations and workshops with Matawa First Nations supported an Indigenous perspective of FPIC, emerging within an Indigenous worldview, as a relational concept, in contrast to the fragmented Western interpretation and application of FPIC. Taking a relational approach is critical as it includes Indigenous law, knowledge, and philosophy. An Indigenous cosmology is what many Indigenous nations refer to as their “original instructions," part of Indigenous legal traditions (Borrows, 2005; Coyle, 2017). Although these philosophies are diverse amongst Indigenous Peoples, they are similar in articulating Indigenous Peoples' sophisticated relationship with all elements of the universe.

Indigenous philosophy is based upon a sacred duty and responsibility to live in a harmonious manner with the natural world. Indigenous philosophy is the necessary foundation for weighing the benefits or harms central to consent seeking and the crafting of an impact benefit agreement. This means that Indigenous communities will be considering their sacred duty and responsibility to protect the land and ecosystems for future generations, as they attempt to balance the impacts of development upon Mother Earth. This means that achieving a successful consultation and consent process will not simply involve a Western conventional economic lens that will demonstrate financial compensation within a benefit agreement. The consultation and consent seeking processes must reflect Indigenous Peoples' duty to their ongoing responsibilities that will ensure their ultimate survivability and sustainability as Indigenous Peoples. 
The nature of these processes is a vital consideration for extractive industries when they are proposing development in remote areas of Indigenous territories, which most of the Matawa territory is. In many of these areas, there is a limited opportunity for Indigenous people to participate in a modern market economy; many make their livelihood from their traditional lands. Effectively, when these lands are remote and Indigenous people have an active relationship with the land by means of hunting, trapping, and gathering as a primary source of their sustenance, they are still very much a part of their ecosystems.

An extractive industry coming into an ecosystem in which Indigenous Peoples are living in such a relationship with the land must consider the sacredness of this relationship to the land and the nation's cultural activities. When there is disruption in an ecosystem, the potential exists to disrupt the relationship that Indigenous Peoples have with their lands. This then disrupts their ability to fulfill their sacred duty to live this relationship to land, thereby denying their ability to live their Indigeneity without constraint. Indigenous communities will not simply use a Western conventional economic philosophy that teaches that the duty of the human race is to gain control over the environment, to utilize its resources, and to assert dominance as a species, as this directly contravenes Indigenous philosophies that commonly centre on seeking a relationship of perfect balance with all things in the universe (Loomis, 2000).

The need for a relational approach to FPIC has been identified by others who suggest that doing so would help to shift away from the consent-as-veto discourse towards one which engages Indigenous Peoples as full partners where the goal is to reach a mutually agreeable outcome (Papillon \& Rodon, 2016). However, essential to this relational position is the reality that "the possibility that the Indigenous group may withhold its consent has to remain on the table throughout the process" (p. 3). By recognizing an Indigenous relational approach to the principles and practices of FPIC, we strive to advance the full utility and implementation of FPIC as a rights framework that can advance positive relationships of co-existence and mutually beneficial economic partnerships and/or protected Indigenous territories. Advancing Indigenous philosophies and understanding of the meaning and processes of free, prior, and informed consent will allow the principles of FPIC to become increasingly aligned with Indigenous Peoples' duties and responsibilities to the land and future generations, along with international rights frameworks and Indigenous inherent and legal rights. A relational approach to consultation and consent seeking, informed by Indigenous knowledge and worldviews, will be a more fully informed process without which industrial and extraction activities threaten Indigenous Peoples, their rights, and their freedom to practice their Indigeneity.

The relational approach to FPIC reveals the ontological divide between Indigenous and non-Indigenous worldviews and relationships to land, as well as the very meaning of relationship itself. In developing a relational approach to FPIC, non-Indigenous individuals, whether government or industry representatives, need to be able to acknowledge the deeper meaning of Indigenous worldviews and the essential cultural meaning of relationship. Non-Indigenous participants need to recognize that there is a plurality of legal frameworks in which both Western and Indigenous laws exist and inform decisionmaking processes. The idea, however, is not to focus on the differences, but to respect one another and to work towards decision-making processes regarding land and resource stewardship and "development" founded on respectful relationships. Indigenous communities are asking for a return to relationships that are respectful of an Indigenous worldview, meaning a return to equal relations, to the respect for selfdetermination, and acknowledgement of one another as sovereign beings, each as part of the larger 
ecosystem and universe. The importance of relationship within FPIC has been indicated for some time; however, as participants described in this study, FPIC principles are not being fulfilled as requisites of a relational, consent-seeking process in the practices of governments and industry on Indigenous territories. The recent Federal Court of Appeal decision on the inadequacy of the Crown's consultation process in the matter of the Trans Mountain pipeline (Tsleil-Waututh Nation v. Canada (Attorney General), 2018) speaks to the importance and necessity of a "two-way dialogue" rooted in respectful relationships. The Crown's failure to understand the relational aspect of the right to FPIC has proven costly to industry, governments, and Indigenous communities.

It has been suggested that Indigenous Peoples have the right to withhold consent, but exercising this right should be subject to tests of necessity and proportionality (Anaya, 2013). In the Tsilhqot'in First Nation v. British Columbia (2014) case, the Supreme Court of Canada determined that consent is not absolute and that the Crown may still infringe on Indigenous rights for compelling reasons. The issue of consent, therefore, remains unclear and contested under Canada's current duty to consult and accommodate guidelines.

In advancing a relational approach to FPIC, we agree with the notion of working together towards considering the needs of the larger community to promote peaceful coexistence; however, we question the current discourse that assumes Indigenous Peoples do not have jurisdiction over their territories. This assumption implies that the "good of all" is a potentially limiting factor to Indigenous Peoples' inherent rights to live as they choose on their lands, especially when the greater good is defined by those with a vested interest in development. In this case, Indigenous Peoples are calculated into the body of the "all." The power and potential of FPIC lies in the right to exercise self-determination by collectively exercising the authority to make deliberations and decisions about one's own territory and lifeways. A mutual understanding of what consent means within FPIC is essential to the advancement of Indigenous rights and a necessary tool for Indigenous Peoples to exercise in order to "diminish coercion in relations of deep asymmetry" (Leydet, 2019, p. 1).

\section{Conclusion}

Understanding the FPIC principles from an Indigenous perspective goes well beyond the basic definitions currently provided in the technical and legal literature. One of the most important insights gained from our conversations with Matawa First Nations is that FPIC is relational. In other words, the principle of FPIC is one that depends on meaningful relationships between First Nations, government, industry, and the land.

FPIC requires that relationships are established in which the self-determination of First Nations is respected and honoured. This means that representatives of government and industry must become aware of Indigenous rights and cultures, as well and their respective relational responsibilities in their roles while fulfilling the duty to consult. A relational process of FPIC would require that government representatives and industry proponents are informed about Canadian law, treaties, and international law, as well as the cultures, worldviews, histories, languages, and rights of the Indigenous Peoples they seek to communicate with, prior to processes of consultation and consent seeking. The development of respectful relationships by those who are seeking access to resources on Indigenous lands is a reasonable first step that would begin to offset the deep asymmetry of power that has been exercised between 
government, industry, and Indigenous communities. Relationship building would involve meeting where the Indigenous community leaders choose, communicating in their preferred language, and respecting local protocols well in advance of any prospecting or permitting in relation to proposed developments affecting Indigenous lands and resources.

We have seen a bold and promising shift towards recognizing Indigenous rights and the importance of relationships by the current Prime Minister of Canada, Justin Trudeau, in such statements as:

No relationship is more important to Canada than the relationship with Indigenous Peoples. Our Government is working together with Indigenous Peoples to build a nation-to-nation, Inuit-Crown, government-to-government relationship—one based on respect, partnership, and recognition of rights. (Trudeau, 2017, para. 3)

Despite the rhetorical emphasis on relationship in recent federal announcements, the natural resource relationship is, however, still very one sided and the words have begun to ring hollow. Matawa First Nations' observations about current consultation processes and the need for consent based on selfdetermination reflect a pervasive frustration about inadequate consultation processes experienced by First Nations across Canada. Relationships are a two-way street.

While the federal government is speaking about the importance of a nation-to-nation relationship, the provinces and territories are still directing the processes of consultation and consent seeking. The lack of international standards for the interpretation, implementation, and monitoring of FPIC is at issue in this article. Further barriers are presented by federal-provincial jurisdiction confusion, where the federal government is responsible for exercising its fiduciary obligation to "Indians and Lands reserved for the Indians" (Constitution Act, 1867), while the provinces, through separate and varied provincial and territorial government policies and processes, assert jurisdiction over Indigenous lands and resources, subject to the duty to consult.

There is a tremendous irony in consent seeking, which is arguably, at this point in time, seen by government and industry as a process of securing agreement versus a legitimate process of free, prior, and informed consent seeking. If consent cannot be withheld after reviewing information, community consultation, and collective decision making, then free consent cannot, for all intents and purposes, be sought or given.

Upholding the inherent and international rights of FPIC will require a focus on renewed relationships based on mutual respect and trust, a shifting of power, attention to and a deeper understanding of Indigenous worldviews. The full realization of FPIC in Canada, as an expression of Indigenous selfdetermination, fostered through the "building of respectful relationships," as outlined in the TRC's (2015) Calls to Action 92, will therefore be an essential step towards reconciliation in Canada.

\section{References}

Anaya, J. (2013). Report of the Special Rapporteur on the rights of Indigenous Peoples, James Anaya (No. A/HRC/24/41). United Nations Human Rights Council. Retrieved from http://unsr.jamesanaya.org/docs/annual/2013-hrc-annual-report-en.pdf 
Boreal Leadership Council (BLC). (2012). Free, prior and informed consent in Canada: A summary of key issues, lessons, and case studies towards practical guidance for developers and Aboriginal communities. Retrieved from http://borealcouncil.ca/wp-content/uploads/2013/09/ FPICReport-English-web.pdf

Borrows, J. (2005). Indigenous legal traditions in Canada. Washington University Journal of Law \& Policy, 19, 167-223.

Borrows. J. (2018). How the United Nations declaration on rights changes Canada's relationship with Indigenous Peoples [video]. Retrieved from Centre for International Governance Innovation website: https://www.cigionline.org/multimedia/how-united-nations-declaration-rightschanges-canadas-relationship-indigenous-peoples

Boutilier, S. (2017). Free, prior and informed consent and reconciliation in Canada: Proposals to implement Articles 19 and 32 of the UN Declaration on the Rights of Indigenous Peoples. Western Journal of Legal Studies, 7, 1-21.

Chong, J. (2014). Resource development in Canada: A case study of the Ring of Fire (Background Paper No. 2014-17-E). Ottawa, Canada: Economics, Resources, and International Affairs Division, Parliamentary Information and Research Service, Library of Parliament.

Clyde River (Hamlet) v. Petroleum Geo-Services Inc., 2017 SCC 40, [2017] 1 S. C. R. 1069. Retrieved from https://scc-csc.lexum.com/scc-csc/scc-csc/en/item/16743/index.do

Constitution Act, 1867, 30 \& 31 Victoria, c. 3 (U.K.).

Constitution Act, 1982, being Schedule B to the Canada Act 1982 (UK), 1982, c 11. Retrieved from http://laws-lois.justice.gc.ca/eng/const/page-16.html\#h-52

Coyle, M. (2017). Indigenous legal orders in Canada: A literature review. Law Publications, 92. Retrieved from http://ir.lib.uwo.ca/lawpub/92

Craft, A., Gunn, B. L., Knockwood, C., Christie, G., Askey, H., Youngblood Henderson, J., Borrows, J., Nichols, J., Wilkins, K. Chartrand, L., Fitzgerald, O., Hamilton, R., Beaton, R., Morales, S. \& Lightfoot, S. (2018). UNDRIP implementation: More reflections on the braiding of international, domestic and Indigenous laws. Special report. Waterloo ON and Saskatoon SK: Centre for International Governance Innovation (CIGI) and Wiyasiwewin Mikiwahp Native Law Centre. Retrieved from https://www.cigionline.org/publications/undrip-implementation$\underline{\text { more-reflections-braiding-international-domestic-and-indigenous }}$

Delgamuukw v. British Columbia, [1997]. 3 S.C.R. 1010. Retrieved from https://scccsc.lexum.com/scc-csc/scc-csc/en/item/1569/index.do

Department of Justice Canada. (2018). Principles respecting the Government of Canada's relationship with Indigenous Peoples. Ottawa, Canada: Her Majesty the Queen in Right of Canada.

Retrieved from https://www.justice.gc.ca/eng/csj-sjc/principles.pdf 
Doyle, C. \& Cariño, J. (2013). Making free prior \& informed consent a reality: Indigenous Peoples and the extractive sector. Executive summary. London and Kingham, UK: Indigenous Peoples Links (PIPLinks), Middlesex University School of Law, and The Ecumenical Council for Corporate Responsibility. Retrieved from http://www.piplinks.org/system/files/Making+FPIC+a+ $\underline{\text { Reality+Indigenous }+ \text { Peoples }+\% 2526+\text { the }+ \text { Extractive }+ \text { Sector+Executive+Summary.pdf }}$

Drake, K. (2015). The trials and tribulations of Ontario's Mining Act: The duty to consult and Anishinaabek Law. JSDLP-RDPDD, 11(2), 183-218.

Eabametoong First Nation v. Minister of Northern Development, 2018 ONSC 4316.

Far North Act, 2010, S.O. 2010, c. 18. Retrieved from https://www.ontario.ca/laws/statute/ $\underline{10 \mathrm{f} 18 \text { ? search }=\text { far }+ \text { north }+ \text { act }}$

Food and Agriculture Organization of the United Nations (FAO). (2016). Free prior and informed consent: An Indigenous Peoples' right and a good practice for local communities. Manual for Project Practitioners. Retrieved from http://www.fao.org/3/a-i6190e.pdf

Gardner, H. L., Tsuji, S. R., McCarthy, D. D., Whitelaw, G. S., \& Tsuji, L. J. (2012). The Far North Act (2010) consultative process: A new beginning or the reinforcement of an unacceptable relationship in northern Ontario, Canada? The International Indigenous Policy Journal, 3(2), 7. doi: https://doi.org/10.18584/iipj.2012.3.2.7

Haida Nation v. British Columbia (Minister of Forests), [2004] 3 S.C.R. 511, SCC 73. Retrieved from https://scc-csc.lexum.com/scc-csc/scc-csc/en/item/2189/index.do

Hewitt, J.G. (2018). Options for implementing UNDRIP without creating another empty box. In UNDRIP Implementation: Braiding of international, domestic and Indigenous laws. Special report (pp. 56-62). Waterloo and Saskatoon, Canada: Centre for International Governance Innovation (CIGI) and Wiyasiwewin Mikiwahp Native Law Centre.

Indigenous and Northern Affairs Canada. (2010). Canada's statement of support on the United Nations Declaration on the Rights of Indigenous Peoples. Retrieved from https://www.aadncaandc.gc.ca/eng/1309374239861/1309374546142

International Council on Mining and Metals (ICMM). (2013). Position statement on Indigenous Peoples and mining. London, UK: Author. Retrieved from https://www.icmm.com/website/ publications/pdfs/commitments/2013 icmm-ps indigenous-people.pdf

International Indian Treaty Council (IITC). (2013). Indigenous Peoples and the right to free, prior and informed consent. Retrieved from https://www.iitc.org/wpcontent/uploads/2014/07/Indigenous-Peoples-and-the-Right-to-Free-Prior-and-InformedConsent_121013-WEB.pdf 
International Labour Organization (ILO). (1989). Convention 169 (ILO\#169) Indigenous and Tribal Peoples. Geneva, 76th ILC session. Retrieved from http://www.ilo.org/dyn/normlex/en/f? p=NORMLEXPUB:12100:0::NO::P12100_ILO_CODE:C169

Justice Minister Jody Wilson-Raybould says adopting UNDRIP into Canadian law 'unworkable.' (2016, July 12). APTN National News. Retrieved from https://aptnnews.ca/2016/07/12/justiceminister-jody-wilson-raybould-says-adopting-undrip-into-canadian-law-unworkable/

Land, L. 2016. Who's afraid of the big, bad FPIC? The evolving integration of the United Nations Declaration on the Rights of Indigenous Peoples into Canadian law and policy. Northern Public Affairs, 4(2), 42-49. Retrieved from http://www.northernpublicaffairs.ca/index/wpcontent/uploads/2016/05/NPA-Volume-4-Issue-2-pg-42-49.pdf

Leydet, D. (2019). The power to consent: Indigenous Peoples, states, and development projects. University of Toronto Law Journal, 69(3), 371-403. doi: https://doi.org/ $\underline{10.3138 / \text { utlj.2018-0068 }}$

Loomis, T. (2000). Indigenous populations and sustainable development: Building on Indigenous approaches to holistic, self-determined development. World Development, 28, 893-910. doi: https://doi.org/10.1016/S0305-750X(99)00162-X

Manuel, A. (2017). The reconciliation manifesto: Recovering the land, rebuilding the economy. Toronto, Canada: James Lorimer Publishers.

McKenzie, J-L. (2019, February 27). Ontario government reviewing, possibly repealing the Far North Act. $C B C N e w s$. Retrieved from https://www.cbc.ca/news/canada/sudbury/far-north-act-firstnations-repeal-1.5034526

Mikisew Cree First Nation v. Canada (Minister of Canadian Heritage), [2005] 3 S.C.R. 388, 2005 SCC 69. Retrieved from https://scc-csc.lexum.com/scc-csc/scc-csc/en/item/2251/index.do

Mining Act, R.S.O. 1990, c. M.14. Retrieved from https://www.ontario.ca/laws/statute/90m14

Motoc, A. \& Tebtebba Foundation. (2005). Standard-setting: Legal commentary on the concept of free, prior, and informed consent (E/CN.4/Sub.2/AC.4/2005/2). Commission on Human Rights Sub-Commission on the Promotion and Protection of Human Rights Working Group on Indigenous Populations (23rd session). Retrieved from https://www.ohchr.org/documents/issues/ipeoples/wg/e-cn4-sub2-ac4-2005-wp1.doc

Morales, S. (2017). Braiding the incommensurable: Indigenous legal traditions and the duty to consult. In UNDRIP Implementation: Braiding of international, domestic and Indigenous laws. Special report (pp. 63-78). Waterloo and Saskatoon, Canada: Centre for International Governance Innovation (CIGI) and Wiyasiwewin Mikiwahp Native Law Centre.

Office of the United Nations High Commissioner for Human Rights (OHCHR). (1997). Committee on the Elimination of Racial Discrimination (CERD) general recommendation No. 23: 
Indigenous Peoples. Geneva, 51st session. Retrieved from http://hrlibrary.umn.edu/ gencomm/genrexxiii.htm

Office of the United Nations High Commissioner for Human Rights (OHCHR). (2013). Free, prior and informed consent of Indigenous Peoples. Retrieved from http://www.ohchr.org/Documents/Issues/IPeoples/FreePriorandInformedConsent.pdf

Ontario Chamber of Commerce (OCC). (2014). Beneath the surface: Uncovering the economic potential of Ontario's Ring of Fire. Retrieved from http://www.occ.ca/wpcontent/uploads/Beneath the Surface web-1.pdf

Oxfam. (2015). Community Consent Index 2015: Oil, gas, and mining company public positions on free, prior, and informed consent. Retrieved from https://d1tn3vj7xz9fdh.cloudfront.net/s3fspublic/file attachments/bp207-community-consent-index-230715-en_0.pdf

Papillon, M. \& Rodon, T. (2016). Proponent-Indigenous agreements and the implementation of the right to free, prior, and informed consent in Canada. Environmental Impact Assessment Review, 62, 216-224. doi: https://doi.org/10.1016/j.eiar.2016.06.009

Sustainable Development Institute and Social Entrepreneurs for Sustainable Development. (2015). Communities in the driving seat: A manual on free, prior and informed consent. Retrieved from https://www.sesdev.org/publications/fpic training manual.pdf

Tauli-Corpuz, V. (2018). Attacks and criminalization of Indigenous Peoples defending their lands and rights. Report of the Special Rapporteur on the Rights of Indigenous Peoples. Retrieved from https://www.theyshouldhaveknownbetter.com/report

Trudeau. J. (2017). Statement by the Prime Minister of Canada on National Aboriginal Day. Retrieved from https://pm.gc.ca/eng/news/2017/06/21/statement-prime-minister-canada-nationalaboriginal-day

Truth and Reconciliation Commission of Canada (TRC). (2015). Truth and Reconciliation Commission of Canada: Calls to action. Retrieved from http://trc.ca/assets/pdf/ Calls to Action_English2.pdf

Tsilhqot'in Nation v. British Columbia, 20142 S.C.R. 256, SCC 44. Retrieved from https://scccsc.lexum.com/scc-csc/scc-csc/en/item/14246/index.do

Tsleil-Waututh Nation v. Canada (Attorney General), 2018 FCA 153. Retrieved from https://decisions.fca-caf.gc.ca/fca-caf/decisions/en/item/343511/index.do\#_Remedy

Udofia, A., Noble, B., \& Poelzer, G. (2017). Meaningful and efficient? Enduring challenges to Aboriginal participation in environmental assessment. Environmental Impact Assessment Review, 65, 164174. 
Union of BC Indian Chiefs (UBCIC) \& Canadian Centre for Policy Alternatives (CCPA). (2018). True, lasting reconciliation: Implementing the United Nations Declaration on the Rights of Indigenous Peoples in British Columbia law, practices and policy. Retrieved from https://www.policyalternatives.ca/sites/default/files/uploads/publications/BC\%20Office/201 8/11/CCPA-BC_UBCIC TrueLastingReconciliation full 181126.pdf

United Nations. (2007). United Nations Declaration on the Rights of Indigenous Peoples. Retrieved from http://www.un.org/esa/socdev/unpfii/documents/DRIPS_en.pdf

United Nations Committee on the Elimination of Racial Discrimination (CERD). (2017). Concluding observations on the combined twenty-first to twenty-third periodic reports of Canada (CERD/C/CAN/CO/21-23). Retrieved from http://docstore.ohchr.org/SelfServices/

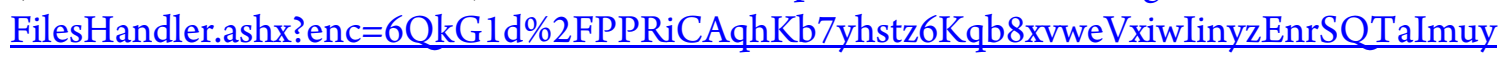
oLPtH1p\%2B\%2FBoA9aSpHnHOaSTR3D\%2BGaG21xFo2B95JnqHNgalSwJoOiSGBGOUk 6xxJIGD9T1UIJq2pb\%2BLbXWwAtxJ\%2FiP6NJCzvYQ\%3D\%3D

United Nations General Assembly. (1960). Declaration on the Granting of Independence to Colonial Countries and Peoples (A/RES/1514(XV)). Retrieved from https://www.un.org/ga/search/view doc.asp?symbol=A/RES/1514(XV)

United Nations General Assembly. (2014). Outcome document of the high-level plenary meeting of the General Assembly known as the World Conference on Indigenous Peoples (A/RES/69/2). Retrieved from http://www.un.org/en/ga/69/meetings/indigenous/\#\&panel1-1

Ward, T. (2011). The rights to free, prior and informed consent: Indigenous Peoples' participation in rights within international law. Northwestern Journal of International Human Rights, 10(2), 5484. Retrieved from http://scholarlycommons.law.northwestern.edu/njihr/vol10/iss $2 / 2$

Weitzner, V. (2011). Tipping the power balance: Making free, prior and informed consent work. Ottawa, Canada: The North-South Institute. Retrieved from http://www.nsi-ins.ca/wpcontent/uploads/2012/10/2011-Tipping-the-Power-Balance-Making-Free-Prior-andInformed-Consent-Work.pdf 